\title{
Challenging the Masculine Generic
}

\section{Susan Knutson}

Gender is not only a function of grammar, but its product. Gender is an ordering system governed by the play of grammatical codes. According to the grammar we inherited from the Indo-Europeans, the feminine is the marked gender, and the masculine is the unmarked, or generic. Some theorists, thinking perhaps of the phallus, or of the relegation of the feminine to negative semantic space, have represented this opposition as plus or minus male. The best evidence, however, would see it as plus or minus female. In patriarchal history the feminine is a kind of scarlet letter, a mark of Eve, which opposes woman not to man but to Man, whose figure looms between herself and the angels. As for her, she is meant to provide passageway to earth.

Gender is a function and a product of grammar at the level of the sentence, at the level of discourse, and at the level of narrative. The masculine generic exists without difficulty today in all these areas of language use. It is well known that the masculine generic is a grammatical characteristic of Indo-European languages. It is less often recognised that at the level of discourse - parole - the masculine generic works insidiously to empower men and to silence women and girls. ${ }^{\text {In }}$ the everyday speech of ordinary people it works alongside a host of familiar oppositions to create a lop-sided, asymmetrical and gendered view of the world. In addition, recent research has identified the masculine generic operating at the level of narrative. ${ }^{2}$

Gender and language have been the subject of over ten years of intensive linguistic research and lobbying for language reform. Some contemporary authors have begun to employ a feminine generic in their writing, at the level of the sentence. Some feminist discourse has clearly established a feminine generic within its own confines, at the level of discourse. Some creative writers are working to disrupt the masculine generic at the level of narrative, and to find other ways to make sense of the world. We have witnessed the birth of writing au féminin. It is in the context of the discoveries of feminist linguistics that writing "in the feminine" can be fully appreciated as a feminist strategy for the appropriation of meaning. This paper reviews the question of the masculine generic, exploring again the idea of working "in, with and against language" to identify and subvert the gendered categories of reality that language is coded to produce. ${ }^{3}$ 
For any member of a speaking community, language provides the best model available of reality, and in fact it is widely accepted that reality cannot be apprehended directly but is mediated through language. This is because meaning does not reside in things, or even in words, but in the articulation of differences within signifying systems. These differences are thought to be coded in binary oppositions such as [p] [b], or \pm voiced; or [masculine] [feminine], or \pm marked. One might expect that [masculine] [feminine] would be seen as an opposition particularly productive of meaning, but in fact this has not been the case. On the contrary, many modern linguists have taken pains to deny any social relevance to the gender opposition in language.

Feminist historians of linguistics have demonstrated that this was not always the case: from the 16th century on, English grammarians were content to shore up the masculine generic on the grounds that the male was a worthier gender. For example,

Some will set the carte before the horse, as thus. My mother and my father are both at home, euen as thoughe the good man of the house ware no breaches, or that the graye Mare were the better Horse. And what thoughe it often so happenenth (Got wotte the more pitye) yet in speakinge at the leaste, let vs kepe a natural order, and set the man before the woman for maners sake. ${ }^{4}$

Exposing the motivations of traditional grammar is one of the ways that modern feminist linguistics has worked to demonstrate the meaningfulness of gender in language.

Contemporary linguistics emphasizes the distinction between natural and grammatical gender. English is considered to be relatively gender-free, employing only natural gender - beings biologically male and female are identified as such. This is seen as unproblematic. Feminist linguists have shown that the situation is not quite that simple. "A more objective look at language use reveals that gender in English is not entirely natural, and that gender in such languages as Latin, French and German is not entirely grammatical." Enormous lexical asymmetry, the existence of sex-marked predicates, the use of the masculine as generic and the masculine gender of most agency nouns, stretching back to Indo-European, all work together to create a lop-sided, anti-woman view of the world. This has led feminists to posit far-reaching linguistic generalizations such as the existence of a semantic rule which de-valorizes terms for women, ${ }^{6}$ and the relegation of women to "negative semantic space." 
French has a combination of "unproblematic" natural gender and grammatical gender which is not supposed to be meaningful. "Du point de vue de sens, le genre constitute, selon la pittoresque, mais judicieuse expression des grammairiens Damourette et Pichon, un 'sexe fictif.' ${ }^{\circ}$ Speaking from a feminist perspective, we could agree with this; femininity as it is created by gender in language is no doubt a fiction, albeit a rather pervasive one. Unfortunately, what is meant is that grammatical gender has no semantic content - an assertion we are refuting. In fact, all of the gender-related problems which exist in English also exist in French, and in addition there are many more arising from the particular functions of grammatical gender.

Word counting, as Dale Spender noted, is one of the most readily available ways of shoring up the feminist assertion that language is sexist. Lexical asymmetry is the rule rather than the exception; there are simply many more words to create/describe male reality than there are to create/describe the experience of women. Furthermore, words for women tend to be derogatory. Julia Penelope (Stanley), one of the earliest word counters who continues to make a major contribution to feminist linguistics, pointed out in 1973 that there were two hundred and twenty words for promiscuous females in English, and only twenty for males. 9 There are huge gaps in our vocabularies with words like 'potent' and 'virile' available to men only, without feminine equivalents. Some words for women's realities have simply been suppressed, as Benoîte Groult has pointed out:

Pierre Guiraud, un grammairien mort récemment, dans son très intéressant dictionnaire érotique, dénombre 70 mots pour l'anatomie du sexe féminin, presque tous injurieux, orduriers ou ridicules, et 550 appellations pour l'organe mâle, toutes plus glorieuses et flatteuses les unes que les autres.

Le mot "clitoris" par exemple, ne figurait pas dans la Grande Encyclopédie au début du vingtième siècle; cette carence du langage face à l'anatomie du sexe féminin nous a empêchées de connaître, faute de mots, notre propre corps. Et ce rejet du corps des femmes date des Pères de l'Eglise! Linné a froidement déclaré: "Je n'entreprendrai pas la description des organes féminins car ils sont abominables!" 10

Other words have been lost as the realities corresponding to them disappeared. Julia Penelope (Stanley) and Cynthia McGowan located three such words in Old English:

As the range of social opportunities for wimmin continued to narrow, so, too, did the available terms which designated 
female participation in social activities outside the home, witness the loss of locbore 'free woman,' guocwena 'battle woman,' and maedenbeap band of female warriors."

This dialectical relationship governing language and social reality is equally apparent in the positive lexical changes of recent years which are attributable to the power of the feminist movement. Old words, such as 'sexism,' 'spinster,' and 'patriarchy,' have been reclaimed; new words, such as 'Ms' and 'sexual harassment,' have been coined; and taboo words, such as 'clitoris,' 'dyke' and 'lesbian,' have come into circulation.

In 1978, Penelope (Stanley) and Robbins (Wolfe) published a paper analyzing sex-marked predicates in English, noting that lexical asymmetry is also reinforced by gender specific distributional relationships. ${ }^{12}$ There are verbs which require male or female subjects, for example, 'menstruate,' 'conceive,' or 'ejaculate.' There are others which require gender specific objects: 'castrate,' 'emasculate,' 'fertilize,' and 'deflower.' As might be expected, these gendermarked relationships are asymmetrical and tend to define and reinforce cultural stereotypes of appropriate behavior for women and men.

By far the most widely criticized phenomenon concerning gender and language is the use of the masculine as generic, for example, the use of he/man/mankind to denote the human race. For centuries, prescriptive grammarians of English have tried and failed to eradicate the use of 'they' in sentences such as "Anyone can do it if they really want to." They have argued that correct English usage requires agreement in number, thus: "Anyone can do it if he really wants to." ' $\mathrm{He}$ ' in this sentence is supposed to be generic; it is supposed to mean 'he or she.' It is supposed to be unmarked for gender. Experiments have shown, however, that native English speakers perceive 'he' and 'man' as masculine, and the use of these terms as generic serves to exclude women from the human race. As Casey Miller and Kate Smith put it, "what standard English usage says about males is that they are the species. What it says about females is that they are a sub-species." 13

It has been less widely acknowledged that the use of the masculine generic extends far beyond the use of 'he' and 'man.' In the following sentences, the masculine generic is evident as a function of discursive practice, rather than sentence grammar: 
The lack of vitality is aggravated by the fact that there are so few able-bodied young adults about. They have all gone off to work or look for work, leaving behind the old, the disabled, the women and the children.

\section{The Sunday Times}

A coloured South African who was subjected to racial abuse by his neighbours went berserk with a machete and killed his next-door neighbour's wife, Birmingham Crown Court heard yesterday.

\section{The Guardian ${ }^{14}$}

These examples, and many more could be cited, make it clear that the masculine generic operates on the level of discourse, and is not confined to the use of 'he' or 'man.'

In a critique of Dale Spender's Man Made Language (1980), Maria Black and Rosalind Coward concluded:

Perhaps the masculine generic could be understood not in terms of the hidden male gender of general terms but the fact that the attributes of the male can in fact disappear into a non-gendered subject. Women, on the other hand, never appear as nongendered subjects ... Women are not the norm, but this does not mean they are not defined. The curious feature is exactly the excess of (sexual) definitions and categories for women. ${ }^{15}$

The masculine generic is the mechanism through which language defines women as objects of sexual exchange.

In French, grammatical gender intensifies the problem of the masculine generic. Mixed groups of men and women require masculine pronouns and adjectives, thus rendering women invisible in mixed society. This situation provides a grammatical justification for feminist separatism: only in women-only spaces do women become grammatically visible. A more language-centred strategy that can be, and has been, adopted in French and English is the use of the feminine as generic. Thus Deborah Cameron uses 'she' instead of 'he' or even 's/he' throughout her book on feminist linguistic theory, and Monique Wittig's guérillères remain 'elles' even when, at the end of the book, they are joined by some young men. It is in this use of the feminine as generic that strategies for change based on language as grammar and language as discourse meet in the particular discursive practice which constitutes language "in the feminine." 
No discussion of the role of gender in language would be complete without a consideration of the generally masculine gender of agentnouns and prestigious occupational titles. This is an area in which language change is being actively pursued and feminism can be seen to be having an impact on grammar, particularly in French.

In a 1980 article Susan Wolfe pointed out that in languages of Indo-European origin, nouns denoting agency, such as 'writer,' 'doctor,' 'worker,' or 'professor,' are generally marked [\&male], and this is equally true for those languages which have grammatical gender as it is for English, which does not. ${ }^{16}$ In French, masculine gender is a grammatical feature: 'un médecin,' 'un écrivain.' In English it is implied or understood, and we end up with compounds to indicate the anomalous presence of women in these roles:

To the extent that we can talk about a gender system in English our vocabulary is divided into two separate and unequal portions. The smaller group of nouns, marked as [\&female], consists of those words that refer to culturally-defined female activities and interests ... only a few nouns carry the feature [\&female] ... e.g. 'prostitute,' 'nurse,' 'spider.' . . When a woman becomes a professional in one of the fields usually reserved for males, she does not move into the corresponding semantic label. Instead ... we are accustomed to talking about the 'lady doctor,' a 'female surgeon,' 'women lawyers' . . . we understand any noun that occurs in its "unmarked" form to refer to a male. ${ }^{17}$

Although Penelope (Stanley) here posits semantic rule, her examples rest on the habits of particular speech communities: "we are accustomed to talking about" something. Eight years have passed since this article was published, and the habits of speech communities change. To me, now, the term 'lady doctor' has a distinctly quaint ring. It is not current in my speech community, in which 'matronization' of female professionals is widespread. The influx of women into the medical profession has no doubt eroded the [\&male] marking of 'doctor,' even for the most male-centered individuals.

Conscious feminist effort to implement and support non-sexist language has had an impact and has met with some success, although there have been some failures, too. 'Chairperson' may not survive; 'patriarchy,' like 'capitalism,' is a word that is rarely employed by North American anglophone media. In the case of English, the general strategy is to continue the historical process of de-gendering the language. We fight for the adoption of neutral terms, such as 
'letter carrier,' 'press operator,' and 'sales clerk,' at the same time that we collectively undermine the assumption that prestigious occupational titles are [\&male]. In the case of marked pairs in which the feminine form has acquired derogatory or sexual connotations, women have won access to the [\&male] term. A woman in government is a Governor, not a Governess; several years in graduate school might transform a woman into a Master, but not a Mistress, of the Arts.

The situation in French is more complex and requires a different linguistic strategy. It is important to note, however, that the importance of the material underpinnings is quite parallel; women entering non-traditional work areas are the force behind legislated language change already underway in Québec and Belgium, and contemplated in France:

Le phénomène, relativement récent, de l'accession des femmes à des professions et emplois jusqu'ici réservés aux hommes, est bien connu pour son impact sur la société, l'économie et la famille. On se préoccupe également depuis quelques années, des répercussions proprement linguistiques de cette évolution sociale, et la question de la féminisation des titres, en particulier, fait de plus en plus l'objet de discussions passionées. ${ }^{18}$

The inalterably masculine gender of titles such as 'médicin' and 'écrivain' requires that subsequent pronoun references and adjectives be masculine in form also. This renders women in these roles invisible. It also makes some statements impossible to say. Notwithstanding the fictivity of grammatical gender, the link between biological sex and grammatical gender is powerful enough that French speakers avoid bringing them into conflict. For example, one cannot say "le nouveau professeur [+female] est belle."

Neither the masculine form of the adjective (e.g. beau) nor its feminine form (belle) can be used appropriately in these circumstances without resolving, as it were, the "conflict" between "grammatical" and "natural" gender. Neither "le nouveau professeur est beau" (which necessarily refers to a man) nor "*le nouveau professeur est belle" (which is ungrammatical) is possible. ${ }^{19}$

A native speaker would avoid the noun, with a sentence such as: "Elle est belle, la nouvelle arrivée." It is not surprising that language reformers have resolved to create feminine terms for occupations. 
The situation is complicated by the existence of feminine forms which are diminutive or insulting: une cheffesse, une docteuse, une sculpteuse. The work has been to find or create terms which are both feminine and positive: une chef, une docteure, une sculpteure, une professeure, une auteure. ${ }^{20}$ Thus women are present in language as a positive and powerful force, reflectiing the roles played by actual women in the world. The process works against the tendency for terms for women to be de-valorized; it works in concert with the efforts of feminist artists to make women's culture visible and to create positive images of women.

The cutting edge of these really significant grammatical changes is not the valorization of women's traditional occupations but the entrance of women into non-traditional roles. Likewise, it is not a question of exploring the lacunae, silences or hysteria of women's discourse, but precisely a question of women demonstrating an ability to participate in discourses traditionally considered to be male: women are able to be judges, legislators, and heads of state. What is threatened is the traditional consideration that such discourses are male. This does not mean that feminists have to endorse all aspects of male culture. It does suggest that in relation to language, the most effective long-term strategy may be the appropriation of the generic rather than the construction of a separate women's culture or language. Critical deconstruction of western cultural discourse will be made in association with men, which has of course been very much the case.

These considerations pose an inevitable question. Are we moving towards a genderless world, and if so, is it counter-productive to be putting more gender into the language, as we are doing, particularly in French?

The history of gender in Indo-European languages suggests that masculine/feminine differentiation evolved and developed in accordance with the dynamics and necessities of the cultures using the languages. The asymmetrical, gynophobic gender paradigm which we have inherited is not a recent development; like many other aspects of language it has deep roots in prehistory. Certainly it was characteristic of Classical Latin. The noun for 'friend,' amicus, has a feminine form, amica, which means 'prostitute.' The masculine noun poetal ae 'poet' belongs to the first declension and would normally have been a feminine noun. Evidently grammatical gender came into conflict with natural gender, and the notion that poets must be men was more important than grammatical consistency. ${ }^{21}$ While it is 
discouraging to contemplate the antiquity of these forms, the fact of their antiquity is not surprising. Patriarchy is not a new development, either. More disturbing is the possibility that the new feminine forms for which we are fighting today will eventually become as debased as those of the past. The feminist movement is the only protection against this.

Patriarchal scholarship has not hesitated to use linguistic evidence to ascertain the primordiality of God the Father, patrilocal social organization, and the subordination of women in marriage. Historical linguistics has been used to provide evidence that hierarchical relations between the sexes are "natural" and concomitant with the evolution of the human species. However, Susan Wolfe and Julia Penelope have demonstrated that scholars with strong patriarchal biases have interpreted data according to their expectations, and, of course, found what they were seeking. Using the same data as their ideological opponents, Penelope and Wolfe have demonstrated the existence of a matriarchal, Amazonian culture in early Indo-European times. ${ }^{22}$

A Californian scholar who is not apparently a feminist has published a theory of the origin of $\mathrm{m} / \mathrm{f}$ gender which is of great interest to feminist analysis. Paul Brosman is a scholar of Hittite, the most ancient Indo-European tongue of which we have written evidence. Hittite does not have masculine/feminine gender, and scholars have always assumed it somehow lost it. Brosman is arguing that, on the contrary, Hittite split off from the parent tongue before the masculine/feminine gender developed. According to his analysis, the most ancient "gender" opposition was not between masculine and feminine at all, but between animate and inanimate objects. Sometime around 4500 B.C., nouns with female referents began to be marked off, and "the arbitrary, grammatical form, and semantic pull" all combined to created the marked, feminine grammatical gender. ${ }^{23}$ It makes sense that if women's status was shifting from subject to object - if women were becoming property - this would be reflected in language. Clearly an exciting task is posed for feminist scholarship: the correlation of the rise of patriarchy with the development of feminine grammatical gender in Indo-European.

For feminism, one of the most interesting implications of Brosman's research is that originally the masculine gender was a true generic: it wasn't masculine at all, but active, as humans, male and female, are. The argument can be furthered by the study of etymology and word clusters, such as that undertaken by Penelope and Wolfe 
in "Amazon Etymology," and by poets Daphne Marlatt and Betsy Warland. Analyzing word clusters, we find concepts as female as mother linked to universal notions such as matter, matrix and divinity. A word as marked as 'Amazon' turns out to be related to the verb 'to be able' and such English words as 'may,' 'might,' and 'mighty.' Archaelogical evidence can also be brought to bear. Marija Gimbutas has carefully documented a non-patriarchal, goddessworshipping culture which disappeared from Europe between the fifth and fourth millenia, B.C. ${ }^{24}$ If building culture "in the feminine" means appropriating a universal, non-gendered point of view for women, we can claim for the project the most ancient and venerable of forebears.

Susan Wolfe has written that her research is important because it demonstrates that women's subordination is not biologically based. ${ }^{25}$ It is a fundamental tenet of feminist theory that our status as second sex is something we are able and intend to unlearn. As feminist theory, écriture féminine was criticized because it seemed to pose a problematic female essence in discourse or text. The formulation of language au féminin, or "in the feminine," does not reify the philosophically and politically suspect notion of a feminine essence. To perform any undertaking in the feminine - and we can speak not only of grammar and discourse but also of architecture, music, painting or cinema - is to defy the masculine generic, and to situate women as speaking subjects, at the origin of the meaning we give to words. ${ }^{26}$

\section{Notes}

1 See, however, Maria Black and Rosalind Coward, "Linguistic, Social and Sexual Relations: A Review of Dale Spender's Man Made Language," Screen Education 29 (1981), p. 78.

2 See Teresa de Lauretis, Alice Doesn't: Feminism, Semiotics, Cinema (Bloomington: Indiana U.P., 1984).

3 Louise Cotnoir, "S'écrire avec, dans et contre le langage," trans. Barbara Godard, "Writing Ourselves With, In and Against Language," Tessera, Room of One's Own, Vol. 8, No. 4(1984), pp. 47 - 52. 
4 Thomas Wilson, Arte of Rhetorique [1553] ; rpt. Gainesville, Fla.: Scholars' Facsimiles and Reprints, 1962, p. 189; cited in Denis Baron, Grammar and Gender (New Haven and London: Yale U.P., 1986), p. 3.

5 Baron, p. 109.

6 Muriel Schulz, "The Semantic Derogation of Women," in Barrie Thorne and Nancy Henley, eds., Language and Sex: Difference and Dominance (Rowley, Mass.: Newbury House, 1975).

7 Stanley, Julia P. (a.k.a. Julia Penelope), "Gender-Marking in American English: Usage and Reference," Sexism and Language, eds. Alleen Pace Nilsen et. al. (Urbana, Illinois: National Council of Teachers of English, 1977), pp. 43 - 76.

8 Grammaire Larousse du français contemporain, Jean-Claude Chevalier et. al. (Paris: Librairie Larousse, 1984), p. 164.

9 Julia Stanley [1973] ; cited in Dale Spender, Man Made Language 2nd ed. (London: Routledge and Kegan Paul, 1985), p. 15.

10 "Rencontre du dimanche 24 novembre 1985 avec l'écrivaine Benoîte Groult," Dialogue de Femmes, 12 rue Georges Berger, 75017 , Paris, France, p. 2.

11 Julia Penelope (Stanley) and Cynthia McGowan, "Woman and Wife: Social and Semantic Shifts in English," Papers in Linguistics, Vol. 12, Nos. 3-4 (1979), pp. 500.

12 Julia P. Stanley and Susan Wolfe Robbins, "sex-marked Predicates in English," Papers in Linguistics, Vol. 11, Nos. 1-2 (SpringSummer 1978), pp. 487-516.

13 Casey Miller and Kate Smith, The Handbook on Non-Sexist Writing (Women's Press, 1980), p. 4; cited in Deborah Cameron, Feminism and Linguistic Theory (London: Macmillan, 1985), p. 84.

14 Cited in Cameron, p. 85.

15 Black and Coward, p. 83.

16 Susan J. Wolfe, "Gender and Agency in Indo-European Languages," Papers in Linguistics, Vol. 13, No.4 (1980), pp. 773-794. 
17 Julia Penelope Stanley, cited in Wolfe (1980), p. 777.

18 The French Committee was initiated by the Minister for Women's Rights, Madame Yvette Roudy, and was headed by Benoîte Groult. Their report has not yet resulted in legislation. See André Martin and Henriette Dupuis, La féminisation des titres et les leaders d'opinion: une étude exploratoire, Gouvernement du Québec, 1985, p. 9.

19 John Lyons, Introduction to Theoretical Linguistics (New York: Cambridge U.P., 1969), pp. 286-287; cited in Wolfe (1980), p. 781.

20 Martin and Dupuis, p. 9.

21 Floyd L. Moreland and Rita M. Fleischer, Latin: An Intensive Course (Berkeley: U. of Cal., 1977).

22 Susan J. Wolfe, "Amazon Etymology," Sinister Wisdom 12 (Winter 1980), pp. 15 - 20; Susan J. Wolfe and Julia Penelope Stanley, "Linguistic Problems with Patriarchal Reconstructions of IndoEuropean Culture: A Little More than Kin, a Little Less than Kind," Women's Studies International Quarterly, Vol. 3 (1980), pp. 227 - 237; Susan J. Wolfe, "Constructing and Reconstructing Patriarchy: Sexism and Diachronic Semantics," Papers in Linguistics, Vol. 13, No. 2 (1980), pp. 321 - 344.

23 Paul Brosman, "The Hittite Gender of Cognates of P.I.E. Neuters," Journal of Indo-European Studies, Vol. 6, Nos. 1 \& 2 (Spring/ Summer 1978), pp. 93 - 106; "The Semantics of the Hittite Gender System," Journal of Indo-European Studies, Vol. 7, Nos. 3 \& 4 (Fall/ Winter 1979), pp. 227 - 236; "Designation of Females in Hittite," Journal of Indo-European Studies, Vol. 10. Nos. 1 \& 2 (Spring/Summer 1982), pp. 65 - 70; "The Development of P.I.E. Feminine," Journal of Indo-European Studies, Vol. 10, Nos. 3 \& 4 (Fall/Winter 1982), pp. $253-272$.

24 Gimbutas, Marija, The Gods and Goddesses of Old Europe 7000 3500 B.C. (London: Thames and Hudson, 1974); "An Archaeologists View of *PIE in 1975," Journal of Indo-European Studies, Vol. 3, No. 3 (1975); "The First Wave of Eurasian Steppe Pastoralists into Copper Age Europe," Journal of Indo-European Studies, Vol. 5, No. 4 (Winter 1977), pp. 277 - 338. 
25 Wolfe and Stanley (1980), p. 227.

26 "Interview with Nicole Brossard on Picture Theory," trans. Louise von Flotow-Evans, Canadian Fiction Magazine, No. 47 (1983), p. 122. 